\title{
KAJIAN PENGGUNAAN JENIS IKAN DAN TEPUNG TERIGU PADA KUALITAS KIMIA, FISIK, DAN ORGANOLEPTIK KAMABOKO
}

\author{
Chairil Anwar $^{a^{*}}$, Ika Rezvani Aprita ${ }^{\mathrm{a}}$ Irmayanti $^{\mathrm{b}}$ \\ ${ }^{a}$ Teknologi Pengolahan Hasil Ternak, Politeknik Indonesia, Jl. Bandara Sultan Iskandar Muda Km 12 \\ Kabupaten Aceh Besar, Indonesia \\ ${ }^{\mathrm{b}}$ Teknik Industri Pertanian, Universitas Serambi Mekkah, Jl. T. Imum Lueng Bata, Banda Aceh, Indonesia \\ *Koresponden penulis : chairil_stp@yahoo.com
}

\begin{abstract}
Abstrak
Kamaboko adalah suatu bentuk kue ikan yang terbuat dari gel protein. Penelitian ini bertujuan untuk mengkaji pengaruh jenis ikan (bandeng dan kembung) dan konsentrasi tepung terigu yang digunakan terhadap mutu kamaboko ikan yang dihasilkan. Penelitian ini menggunakan Rancangan Acak Lengkap pola faktorial yang terdiri dari dua faktor yaitu faktor jenis ikan (bandeng dan kembung) dan konsentrasi tepung terigu $(5 \%, 10 \%$, $15 \%$, dan $20 \%$ ) dengan tiga kali ulangan. Hasil penelitian menunjukkan bahwa faktor jenis ikan dan konsentrasi tepung terigu memberikan pengaruh yang nyata terhadap kekenyalan dan kekerasan kamaboko yang dihasilkan. Faktor jenis ikan dan konsentrasi tepung terigu memberikan pengaruh yang sangat nyata terhadap kadar air dan kadar protein kamabako yang dihasilkan. Hasil analisis kimia terhadap kadar protein kamaboko menunjukkan bahwa kamaboko jenis ikan bandeng pada konsentrasi tepung terigu $5 \%$ adalah produk terbaik karena memiliki kadar protein tertinggi yaitu 11,67 \%, sehingga dapat meningkatkan konsumsi protein masyarakat sebagai sumber gizi penting. Hasil uji organoleptik, tingkat penerimaan panelis terhadap warna, penampakan, aroma, rasa, tekstur serta uji potong menunjukkan bahwa kamaboko dengan perlakuan jenis ikan bandeng dengan penambahan tepung terigu pada konsentrasi 5\% merupakan perlakuan terbaik.
\end{abstract}

Kata Kunci: Bandeng, Kembung, Kamaboko, Tepung Terigu

\begin{abstract}
Kamaboko is a form of fish cake made from protein gel. This study aimed to examine the effect of fish species (milkfish and bloating) and the concentration of wheat flour used on kamaboko quality of fish produced. This study used a completely randomized design factorial pattern consisting of two factors, namely the type of fish (milkfish and kembung) and the concentration of flour $(5 \%, 10 \%, 15 \%$, and 20\%) with three replications. The results showed that the type of fish factors and the concentration of wheat flour had a significant influence on the elasticity and hardness of kamaboko produced. Factors of fish species and the concentration of wheat flour had a very significant influence on the water content and the level of kamabako protein produced. The results of chemical analyiss of the kamaboko protein showed that kamaboko type of milkfish at the concentration of 5\% wheat flour was the best product because it had the highest protein content of $11.67 \%$, thus increasing the consumption of community protein as an important source of nutrition. The organoleptic test results, the level of panelist acceptance of color, appearance, aroma, taste, texture and cutting test showed that kamaboko with the treatment of the type of milkfish with the addition of wheat flour at a concentration of 5\% was the best treatment.
\end{abstract}

Keywords: Milkfish, Kembung, Kamaboko, Wheat Flour

\section{PENDAHULUAN}

Ikan sebagai salah satu produk hasil perairan merupakan sumber protein hewani yang paling baik, karena mengandung protein yang cukup tinggi dan komposisi asam amino yang lengkap [1].
Ikan bandeng (Chanos chanos forsk) merupakan salah satu ikan budidaya yang digemari oleh masyarakat sehingga menjadi salah satu komoditas budidaya unggulan. Ikan bandeng memiliki potensi untuk dikembangkan sebagai bahan baku untuk produk olahan yang lebih bervariasi. Ikan bandeng memiliki beberapa keunggulan jika dibandingkan dengan 
jenis ikan lainnya yaitu memiliki rasa cukup enak dan gurih, rasa daging netral dan tidak mudah hancur jika dimasak, serta mengandung protein yang tinggi sebesar $20 \%$ per 100 gram ikan bandeng [2].

Namun demikian ikan merupakan bahan pangan yang mudah rusak (highly perishable food), oleh sebab itu untuk menanggulangi hal tersebut diperlukan suatu cara pengawetan dan pengolahan yang dapat mempertahankan daya awet ikan tanpa mengurangi nilai gizinya, meningkatkan nilai ekonominya dan dapat diterima masyarakat. Salah satu produk hasil pengolahan ikan adalah kamaboko. Kamaboko adalah suatu bentuk kue ikan terbuat dari gel protein yang merupakan makanan tradisonal Jepang. Produk kamaboko ini mirip dengan produk olahan ikan yang sudah lama dikenal masyarakat Indonesia seperti empek-empek Palembang, bakso ikan dan makanan sejenis lainnya. Keistimewaan dari kamaboko ini adalah dapat dibuat dalam aneka ragam bentuk, warna, cita rasa, tergantung dari bumbu dan metode pemanasan yang digunakan, serta dapat disajikan secara langsung [3].

Dalam penelitian ini penulis ingin mencoba menambah variasi produk dari ikan untuk menjadikannya sebagai bahan baku dalam pembuatan kamaboko sehingga produk kamaboko ini dapat disenangi oleh masyarakat luas yang akhirnya dapat meningkatkan konsumsi protein sebagai nilai tambah gizi bagi kesehatan masyarakat.

Mutu kamaboko sangat dipengaruhi oleh jenis ikan yang digunakan, karena setiap jenis ikan mengandung protein yang berbeda sehingga sifat gel kamaboko yang dihasilkan juga akan berbeda. Konsentrasi tepung yang ditambahkan juga sangat berperan penting dalam menentukan sifat-sifat kamaboko khususnya yang berhubungan dengan teksturnya. Jumlah tepung yang ditambahkan di Jepang biasanya berkisar 5-20 \% dari berat surimi yang digunakan [3]. Oleh karena itu dalam penelitian ini dipelajari pengaruh antara jenis ikan dan konsentrasi tepung terigu yang digunakan terhadap mutu kamaboko yang dihasilkan.

\section{MATERI DAN METODE}

\section{Materi Penelitian}

Alat-alat yang digunakan dalam penelitian ini adalah pisau, sendok, wadah plastik, panci pengukus, kompor gas (HITACHI), timbangan, kain saring, chopper (Maxeda), super mincing (Green Power), termometer, cetakan dan stop watch. Sedangkan alat yang digunakan untuk analisis adalah timbangan analitik, peralatan gelas, oven (Philips Clarris), micrographic, fruit hardness tester AST -5, loyang, cawan alumunium, desikator dan labu kjeldahl.

Bahan utama yang digunakan dalam penelitian ini adalah ikan bandeng dan ikan kembung yang masih segar. Bahan-bahan tambahan yang digunakan adalah tepung terigu (segitiga biru), garam, gula, MSG (Ajinomoto), bumbu (bawang merah, bawang putih, merica) serta putih telur. Semua bahan tersebut diperoleh di pasar Lambaro Aceh Besar. Bahan-bahan kimia yang digunakan untuk analisis produk antara lain air, $\mathrm{NaOH}, \mathrm{H}_{2} \mathrm{SO}_{4}, \mathrm{HCl}, \mathrm{Na}_{2} \mathrm{~S}_{2} \mathrm{O}_{3}$, $\mathrm{HgO}, \mathrm{H}_{3} \mathrm{BO}_{3}, \mathrm{~K}_{2} \mathrm{SO}_{4}$.

\section{Metode Penelitian}

Penelitian ini menggunakan Rancangan Acak Lengkap (RAL) pola faktorial yang terdiri dari 2 (dua) faktor yaitu faktor jenis ikan (A) dan konsentrasi tepung terigu (B). Faktor jenis ikan terdiri dari dua taraf, yaitu ikan bandeng (A1) dan ikan kembung (A2). Faktor konsentrasi tepung terdiri dari empat taraf, yaitu 5\% (B1), $10 \%$ (B2), $15 \%$ (B3) dan 20\% (B4). Dengan demikian terdapat delapan kombinasi perlakuan yang diperoleh dari 2 x $4=8$, dengan menggunakan tiga kali ulangan, sehingga diperoleh dua puluh empat satuan percobaan.

\section{Prosedur Penelitian}

Proses pembuatan kamaboko meliputi empat tahap dasar yaitu; pencucian daging ikan, penggilingan daging ikan bersamaan dengan pencampuran bahan tambahan, pencetakan serta pemanasan.

Ikan yang telah dipilih, dilakukan pencucian, penyiangan dan pembuatan fillet. Fillet dicuci untuk menghilangkan darah, komponen lemak, pigmen, lendir yang dapat menyebabkan bau dan warna yang tidak diinginkan serta bertujuan untuk mengekstrak 
protein larut air yang berkaitan dengan pembentukan ashi. Fillet yang dihasilkan diletakkan pada wadah berisi hancuran es untuk mempertahankan kesegarannya. Pelumatan daging ikan dilakukan dengan menggunakan super mincing. Fillet yang telah dilumatkan kemudian dicuci dengan air dingin dengan perbandingan air pencucian dan daging lumat adalah 3:1. Daging lumat yang telah berbentuk bubur halus diaduk-aduk dalam air dingin selama 5 menit hingga pada permukaan air timbul bahan-bahan terapung yang disebut supernatan. Bahan tersebut bersama air pencucian kemudian dibuang.

Perlakuan pencucian dilakukan tiga kali hingga air pencucian berwarna cukup jernih. Setelah pencucian, seluruh air dibuang serta dilakukan penyaringan dan pemerasan dengan menggunakan kain saring sehingga diperoleh surimi. Penggilingan serta percampuran bahanbahan tambahan dilakukan dengan menggunakan copper. Penggilingan dilakukan empat tahap, yaitu : tahap pertama, surimi digiling selama 2 menit, kemudian ditambahkan $3 \%$ garam dan digiling kembali pada tahap kedua selama 2 menit dan dilakukan penambahan tepung $(5 \%, 10 \%, 15 \%$ dan $20 \%)$ sesuai perlakuan. Digiling kembali pada tahap ketiga selama 2 menit dan dilakukan penambahan gula $10 \%$, MSG $1 \%$, bumbubumbu $2 \%$ dan putih telur $10 \%$, selanjutnya digiling kembali pada tahap keempat selama 2 menit sampai bentuk adonan pasta menjadi homogen seluruhnya.

Adonan pasta tersebut harus segera dicetak. Pencetakan dilakukan dalam plastik es panjang PE (polyetilen). Pemanasan dengan metode pengukusan selama 45 menit hingga matang. Produk segera didinginkan, lalu dikemas menggunakan plastik

\section{Analisis Produk}

Pengamatan pada produk kamaboko dilakukan meliputi analisis kimia, analisis fisik, dan uji organoleptik. Analisis kimia yang dilakukan pada produk meliputi kadar air, dan kadar protein. Analisis fisik meliputi uji kekenyalan (elastisitas) dan kekerasan serta melihat struktur penampang kamaboko. Analisis organoleptik meliputi warna, penampakan, rasa, tekstur, dan aroma.

\section{HASIL DAN PEMBAHASAN}

\section{Analisis Kimia}

Kadar Air

Air merupakan bahan yang sangat penting bagi kehidupan manusia dan fungsinya tidak pernah dapat digantikan oleh senyawa lain. Air juga merupakan komponen penting dalam bahan makanan karena air dapat mempengaruhi penampakan, tekstur serta cita rasa makanan [4].

Kadar air kamaboko berkisar antara $58,66 \%-70,66 \%$ dengan rata-rata keseluruhan $64,53 \%$. Hasil analisis ragam menunjukkan bahwa faktor jenis ikan (A) dan konsentrasi tepung terigu (B) memberikan pengaruh yang sangat nyata terhadap kadar air kamaboko. Interaksi antara kedua faktor (AB) memberikan pengaruh yang tidak nyata terhadap kadar air kamaboko yang dihasilkan.

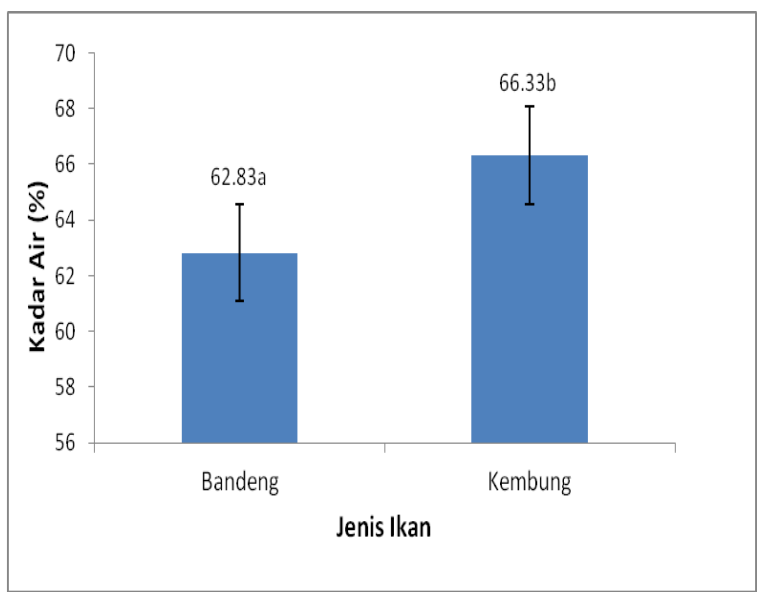

Gambar 1. Grafik Nilai Kadar Air Akibat Pengaruh Jenis Ikan

Hasil uji lanjut BNJ menunjukkan bahwa kadar air kamaboko dari jenis ikan bandeng berbeda nyata dengan kadar air kamaboko dari jenis ikan kembung. Kadar air tertinggi diperoleh dari jenis ikan kembung $(66,33 \%)$ sedangkan kadar air terendah terendah diperoleh dari ikan bandeng $(62,83 \%)$. Hal ini disebabkan karena adanya perbedaan antara kadar air ikan bandeng dan ikan kembung sebagai bahan baku utamanya berbeda, sehingga kadar air kamaboko yang dihasilkan juga tidak sama. Ikan kembung memiliki kadar air yang tinggi yaitu $78 \% \%$, sedangkan kadar air ikan bandeng adalah $72,6 \%$ [5] 


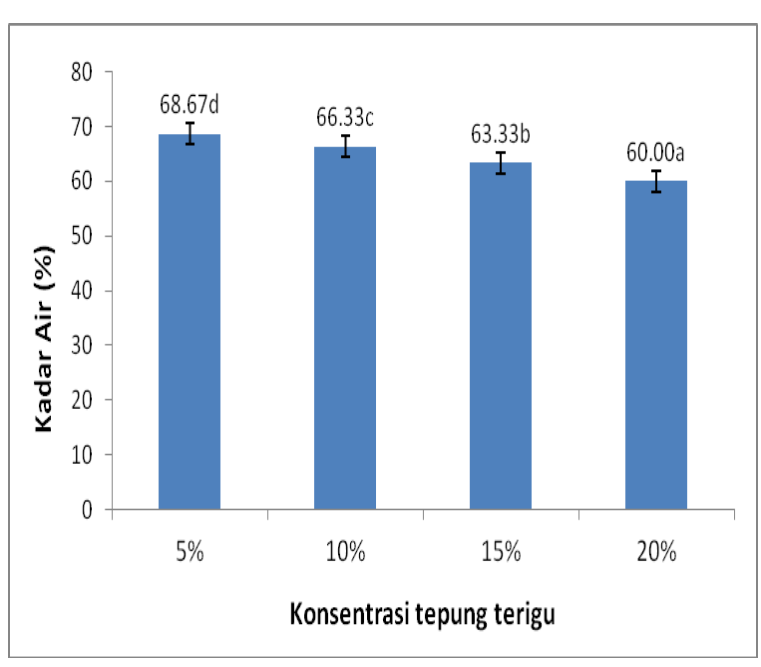

Gambar 2. Grafik Nilai Kadar Air Akibat Pengaruh Konsentrasi Tepung Terigu

Gambar 2 menunjukkan kadar air kamaboko pada konsentrasi tepung terigu 5\% berbeda nyata dengan kadar air kamaboko pada konsentrasi tepung terigu $10 \%, 15 \%$ dan pada konsentrasi tepung terigu $20 \%$. Hasil analisis kadar air kamaboko menunjukkan bahwa nilai kadar air tertinggi terdapat pada kamaboko pada konsentrasi tepung terigu $5 \%$ yaitu $68,67 \%$. sedangkan nilai kadar air terendah terdapat pada kamaboko pada konsentrasi tepung terigu $20 \%$ yaitu $60,00 \%$.

Semakin tinggi konsentrasi tepung terigu yang ditambahkan, maka kadar air kamaboko ikan bandeng dan ikan kembung akan semakin rendah. Hal ini terjadi karena pati yang terkandung dalam tepung terigu menambah berat total dan bersifat menyerap air (hidrofilik), sedangkan kandungan air yang ada di dalam daging ikan tetap, akibatnya persentase kadar air kamaboko menurun.

Penurunan kadar air kamaboko diduga akibat mekanisme interaksi pati dan protein, sehingga air tidak dapat lagi diikat secara sempurna karena ikatan hidrogen yang seharusnya mengikat air telah terpakai untuk interaksi pati dan protein ikan [6].

\section{Kadar Protein}

Protein merupakan suatu zat makanan yang sangat penting bagi tubuh karena zat ini disamping berfungsi sebagai bahan bakar dalam tubuh juga berfungsi sebagai zat pembangun dan pengatur [4]. Kadar protein kamaboko berkisar antara 8,88\%-11,67\% dengan rata-rata keseluruhan $10,17 \%$. Hasil analisis ragam menunjukkan bahwa faktor jenis ikan (A) dan konsentrasi tepung terigu (B) memberikan pengaruh yang sangat nyata terhadap kadar protein kamaboko. Begitu juga interaksi antara kedua faktor $(\mathrm{AB})$ memberikan pengaruh yang sangat nyata terhadap kadar protein kamaboko yang dihasilkan.

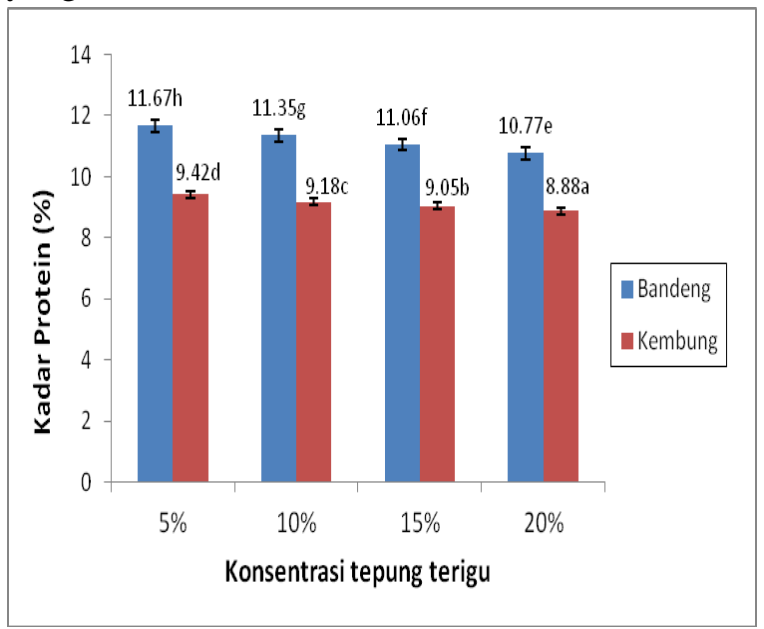

Gambar 3. Grafik Nilai Kadar Protein

Gambar 3 menunjukkan bahwa kadar protein kamaboko berbeda nyata untuk kedua interaksi pada setiap perlakuan. Penggunaan ikan bandeng dan ikan kembung sebagai bahan baku dan penambahan tepung yang berbeda $(5 \%, 10 \%, 15 \%$, dan 20\%) menghasilkan kadar protein yang cenderung menurun. Kadar protein tertinggi diperoleh pada jenis ikan bandeng dan kadar protein terendah pada ikan kembung. Hal ini diduga disebabkan oleh ikan bandeng yang memiliki kandungan protein yang lebih besar dibandingkan ikan kembung. Komposisi ikan bandeng per 100 gram antara lain terdiri dari air $76 \%$; protein $17 \%$; lemak $4,5 \%$; dan mineral $2,52 \%$ [7] sedangkan kandungan gizi ikan kembung per 100 gram adalah energi 103 kkal, protein 22 gram dan lemak 1 gram [8]. Kandungan protein ikan sangat tinggi dibandingkan dengan protein hewani lainnya, dengan asam amino esensial sempurna karena hampir semua asam amino esensial terdapat pada daging ikan [9].

Hasil analisis kadar protein menunjukkan bahwa nilai kadar protein tertinggi terdapat pada kamaboko jenis ikan bandeng $\left(\mathrm{A}_{1}\right)$ pada konsentrasi tepung terigu $5 \%\left(\mathrm{~B}_{1}\right)\left(\mathrm{A}_{1} \mathrm{~B}_{1}\right)$ yaitu $11,67 \%$ sedangkan kadar protein terendah terdapat pada kamaboko jenis ikan kembung 
$\left(\mathrm{A}_{2}\right)$ pada konsentrasi tepung terigu $10 \%\left(\mathrm{~B}_{2}\right)$ $\left(\mathrm{A}_{2} \mathrm{~B}_{2}\right)$ yaitu $8,88 \%$.

Gambar 3 juga menunjukkan bahwa kadar protein kamaboko cenderung menurun dengan meningkatnya konsentrasi tepung terigu. Penambahan tepung terigu menambah total berat kamaboko, sedangkan jumlah protein relatif tetap walaupun secara kuantitatif jumlahnya bertambah dengan adanya kandungan protein pada tepung terigu tetapi bertambahnya protein ini hanya dalam jumlah yang sangat kecil, sehingga perbandingan kadar protein yang ada pada kamaboko dan berat total kamaboko akan tetap mengalami penurunan.

Penurunan protein ini juga disebabkan pada saat pengolahan daging ikan mentah menjadi kamaboko, protein sarkoplasma yang larut dalam air dihilangkan dari daging ikan dengan cara pencucian beberapa kali. Penurunan kadar protein pada kamaboko juga disebabkan protein ikan mudah sekali mengalami kerusakan (denaturasi, penggumpalan, dan perubahan mutu) yang disebabkan oleh proses pengolahan [10].

\section{Analisis Fisik Kekenyalan}

Kekenyalan (elastisitas) adalah kemampuan makanan untuk kembali kebentuk semula setelah diberi tekanan. Analisis kekenyalan gel kamaboko dilakukan dengan mengunakan alat Fruit Hardness Tester AST-5. Sampel ditekan dengan menggunakan alat penekan yang berbentuk head hemisphere shape (berbentuk setengah bola). Kekenyalan $\left(\mathrm{kg} / \mathrm{cm}^{2}\right)$ merupakan perbandingan antara gaya tekan dengan luas head alat penekan.

Kekenyalan kamaboko berkisar antara $0,237 \mathrm{~kg} / \mathrm{cm}^{2}-0,270 \mathrm{~kg} / \mathrm{cm}^{2}$ dengan rata-rata keseluruhan $0,252 \mathrm{~kg} / \mathrm{cm}^{2}$. Hasil analisis ragam menunjukkan bahwa faktor jenis ikan (A) dan konsentrasi tepung terigu (B) memberikan pengaruh yang nyata terhadap kekenyalan kamaboko sedangka interaksi diantara kedua faktor (AB) memberikan pengaruh yang tidak nyata terhadap kekenyalan kamaboko yang dihasilkan.

Hasil uji lanjut $\mathrm{BNJ}_{0,05}$ (Gambar 4) menunjukkan bahwa kekenyalan kamaboko dari kedua jenis ikan berbeda nyata. Kekenyalan kamaboko dari jenis ikan bandeng lebih tinggi dari jenis ikan kembung. Perbedaan ini disebabkan kandungan protein dari kedua jenis ikan berbeda.

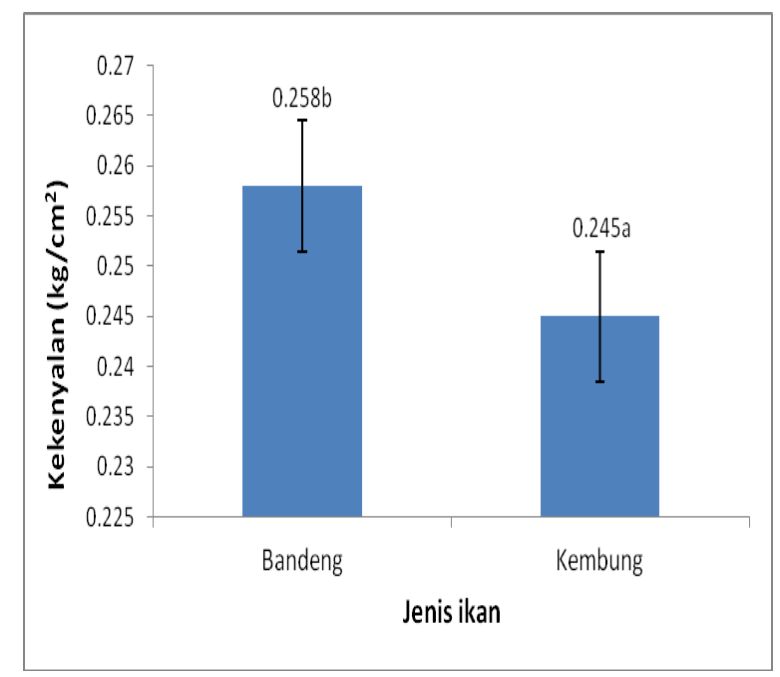

Gambar 4. Grafik Nilai Kekenyalan Akibat Pengaruh Jenis Ikan

Nilai kekenyalan pada kamaboko dipengaruhi oleh konsentrasi protein miofibril yang terkandung di dalam ikan tersebut. Protein tersebut berperan penting terhadap kekenyalan kamaboko [11].

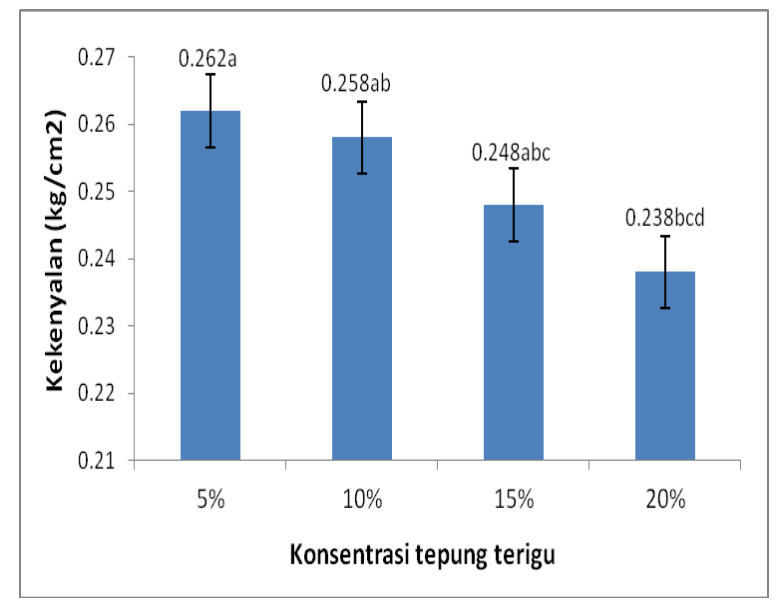

Gambar 5. Grafik Nilai Kekenyalan Akibat Pengaruh Konsentrasi Tepung Terigu

Gambar 5 menunjukkan pengaruh perlakuan konsentrasi tepung terigu terhadap kekenyalan kamaboko. Hasil uji lanjut BNJ kekenyalan kamaboko akibat pengaruh konsentrasi tepung terigu (B), menunjukkan bahwa kekenyalan kamaboko pada konsentrasi tepung terigu $5 \%$ berbeda nyata dengan kekenyalan kamaboko pada konsentrasi tepung terigu $20 \%$ akan tetapi tidak berbeda nyata dengan kekenyalan kamaboko pada konsentrasi 
tepung terigu $10 \%$ dan konsentrasi tepung terigu $15 \%\left(\mathrm{~B}_{3}\right)$.

Hasil analisis kekenyalan kamaboko menunjukkan bahwa nilai kekenyalan tertinggi terdapat pada penambahan tepung terigu 5\% yaitu $0,262 \mathrm{~kg} / \mathrm{cm}^{2}$ sedangkan nilai kekenyalan kamaboko terendah terdapat pada pada konsentrasi tepung terigu $20 \%$ yaitu 0,238 $\mathrm{kg} / \mathrm{cm}^{2}$.

Semakin tinggi konsentrasi tepung terigu yang ditambahkan maka kekenyalan gel ikan semakin menurun. Selama proses pemanasan pati mengalami gelatinisasi, granula pati mengembang dan memerlukan air. Selama perubahan ini granula pati mengembang pada tingkat tertentu melewati struktur jala protein ikan. Mengembangnya granula pati ini menyebabkan tekanan yang kuat pada matrik protein disertai dengan penarikan air yang berada disekitar matrik protein sehingga menghasilkan gel yang lebih kuat. Efek meningkatnya kekuatan gel oleh pati tidak akan terjadi jika gelatinisasi tidak terjadi dalam pasta ikan.

\section{Kekerasan}

Kekerasan adalah gaya yang dibutuhkan untuk menekan suatu bahan atau produk sehingga terjadi perubahan bentuk yang diinginkan. Arti kekerasan pada produk gel adalah daya tahan untuk pecah akibat gaya tekan, yang diawali dengan perubahan bentuk dan dilanjutkan dengan pecahnya produk [12]. Kekerasan kamaboko diukur dengan menggunakan alat Fruit Hardness Tester AST-5. Sampel ditekan dengan menggunakan alat penekan yang berbentuk head cylinder shape (berbentuk kerucut). Kekerasan $\left(\mathrm{kg} / \mathrm{cm}^{2}\right)$ merupakan perbandingan antara gaya tekan dengan luas head alat penekan.

Kekerasan kamaboko berkisar antara $0,47 \mathrm{~kg} / \mathrm{cm}^{2}-0,76 \mathrm{~kg} / \mathrm{cm}^{2}$ dengan rata-rata keseluruhan $0,61 \mathrm{~kg} / \mathrm{cm}^{2}$. Hasil analisis ragam menunjukkan bahwa faktor jenis ikan (A) memberikan pengaruh yang sangat nyata terhadap kekerasan kamaboko. Faktor konsentrasi tepung terigu (B) memberikan pengaruh yang nyata terhadap kekerasan kamaboko sedangkan interaksi antara kedua faktor $(\mathrm{AB})$ memberikan pengaruh yang tidak nyata terhadap kekerasan kamaboko yang dihasilkan.

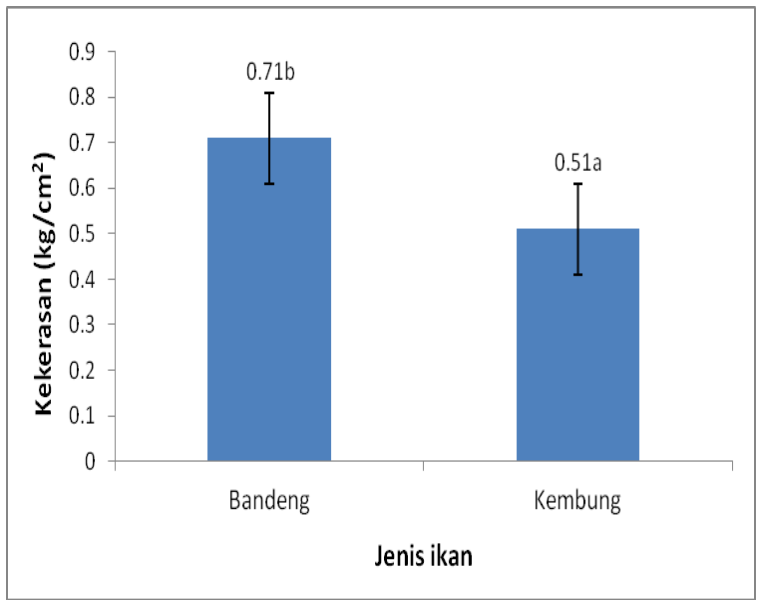

Gambar 6. Grafik Tingkat Kekerasan Akibat Pengaruh Jenis Ikan

Hasil uji lanjut $\mathrm{BNJ}_{0,05}$ kekerasan kamaboko akibat pengaruh jenis ikan menunjukkan bahwa kekerasan kamaboko dari kedua jenis ikan berbeda nyata. Kekerasan kamaboko dari jenis ikan bandeng lebih tinggi $\left(0,71 \mathrm{~kg} / \mathrm{cm}^{2}\right)$ daripada kekerasan kamaboko dari jenis ikan kembung $\left(0.51 \mathrm{~kg} / \mathrm{cm}^{2}\right)$. Perbedaan ini disebabkan kandungan protein dari kedua jenis ikan berbeda. Nilai kekerasan pada kamaboko dipengaruhi oleh konsentrasi protein miofibril yang terkandung di dalam ikan tersebut.

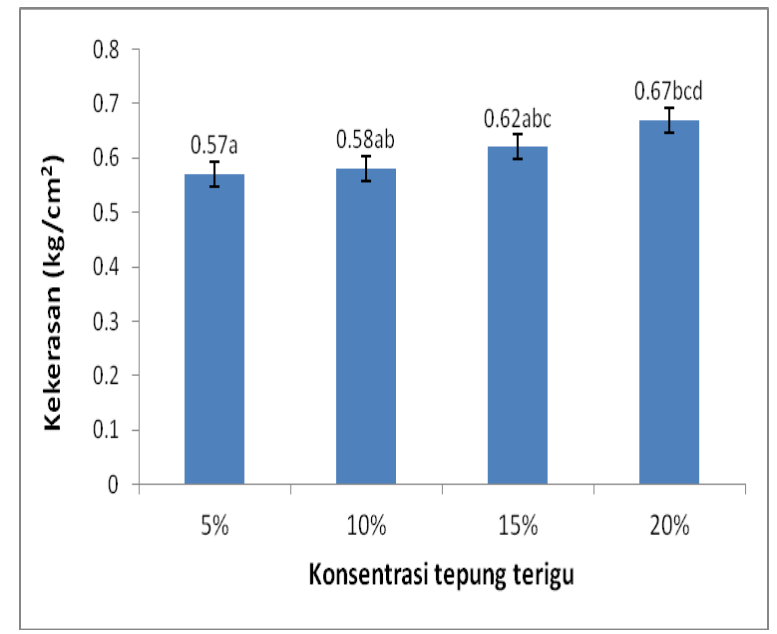

Gambar 7. Grafik Tingkat Kekerasan Akibat Pengaruh Konsentrasi Tepung Terigu

Gambar 7 menunjukkan bahwa kekerasan kamaboko pada konsentrasi tepung terigu $5 \%$ berbeda nyata dengan kekerasan kamaboko pada konsentrasi tepung terigu $20 \%$, akan tetapi tidak berbeda nyata dengan kekerasan kamaboko pada konsentrasi tepung 
terigu $10 \%$, dan pada konsentrasi tepung terigu $15 \%$.

Hasil analisis kekerasan kamaboko menunjukkan bahwa nilai kekerasan tertinggi terdapat pada konsentrasi tepung terigu $20 \%$ yaitu $0,67 \mathrm{~kg} / \mathrm{cm}^{2}$ sedangka nilai kekerasan terendah terdapat pada kamaboko pada konsentrasi tepung terigu $5 \%$ yaitu $0,57 \mathrm{~kg} / \mathrm{cm}^{2}$.

Tingginya kekerasan kamaboko pada ikan bandeng diduga karena kandungan protein miofibril terutama (aktomiosin) pada ikan bandeng yang berperan dalam pembentukan gel kamaboko lebih rendah dibandingkan pada ikan kembung. Hal ini terjadi pada saat pencucian protein miofibril tidak seluruhnya terekstrak oleh garam sehingga pada saat pembuangan air, protein miofibrilnya ikut terbuang, sehingga protein miofibril sebagai protein utama pembentuk gel kamaboko berkurang dengan demikian kekerasan kamaboko dari jenis ikan bandeng lebih tinggi.

Penambahan tepung terigu dapat meningkatkan kekerasan kamaboko, semakin tinggi konsentrasi tepung terigu yang ditambahkan maka kamaboko yang dihasilkan akan semakin keras. Kekerasan kamaboko sangat dipengaruhi oleh adanya pengembangan granula pati. Semakin banyak pati yang ditambahkan, maka air yang terdapat pada bahan juga harus semakin banyak sehingga pati dapat mengembang lebih merata [13].

\section{Struktur Penampang}

Untuk melihat penampang kamaboko dilakukan uji fisik dengan menggunakan alat PhotoMicroscopic yang dilengkapi dengan Photomicrography H-III. Hasil Foto struktur penampang kamaboko dapat dilihat pada gambar 8 Terbentuknya struktur kamaboko ini melalui proses pemanasan, dimana terjadi matrik (protein-pati-air). Proses pemanasan bertujuan agar pati mengalami proses gelatinisasi, sehingga granula pati mengembang dan memerlukan air serta terjadinya denaturasi protein.

Pengembangan granula pati disebabkan molekul-molekul air melakukan penetrasi ke dalam granula dan terperangkap dalam susunan molekul-molekul amilosa dan amilopektin, serta menyebar melewati struktur jala protein ikan. Mengembangnya granula pati tersebut menyebabkan tekanan yang kuat pada matrik protein disertai dengan penarikan air yang berada disekitar matrik protein.

Pemanasan protein dapat mengalami denaturasi, artinya strukturnya berubah bentuk dari unting ganda yang kuat menjadi kendur dan terbuka. Hal ini terutama disebabkan oleh struktur alamiah protein miosin yang labil. Protein terdenaturasi pada rentan suhu $57{ }^{\circ} \mathrm{C}-75$ ${ }^{\circ} \mathrm{C}$ dan ini mempunyai pengaruh yang kuat terhadap tekstur, kemampuan menahan air dan pengerutan. Denaturasi juga dapat mengakibatkan flokulasi protein, tetapi dapat juga mengakibatkan pembentukan gel. Denaturasi dan koagulasi protein suatu bahan yang dapat berikatan dengan susunan dan urutan asam amino dalam protein [14].

Gambar 8 dan 9 dapat dilihat dengan jelas bahwa terdapat perbedaan antara semua perlakuan yang disebabkan oleh terjadinya proses gelatinisasi yaitu proses pengembangan butiran pati oleh air yang irreversible, dimana gelatinisasi ini terjadi jika pati dan air dipanaskan pada suhu kritiknya. Suhu gelatinisasi tergantung juga pada konsentrasi pati, dimana makin kental suatu larutan, maka suhu tersebut semakin lambat tercapai. Hal ini dapat diketahui dengan semakin tinggi konsentrasi tepung terigu yang ditambahkan maka suhu gelatinisasi produk kamaboko semakin lambat. Sehingga pembentukan gel kamaboko tidak akan sempurna, susunan molekul butiran pati menjadi tidak teratur. Semakin tinggi konsentrasi tepung terigu yang ditambahkan maka penampang kamaboko akan semakin padat tetapi teksturnya sedikit tidak rapi, karena semakin banyak air yang terserap oleh pati.

Gambar 8 menunjukkan struktur penampang kamaboko ikan bandeng, sedangkan Gambar 9 menunjukkan struktur penampang kamaboko ikan kembung. Pati gandum memiliki granula yang berbentuk lonjong (lebih memanjang). Struktur kamaboko diantara kedua jenis ikan dengan penambahan tepung terigu pada konsentrasi $15 \%$ dan $20 \%$ terlihat memiliki penampakan yang lebih kompak dan rapat dibandingkan kamaboko dengan penambahan tepung terigu pada konsentrasi $5 \%$ dan $10 \%$. 


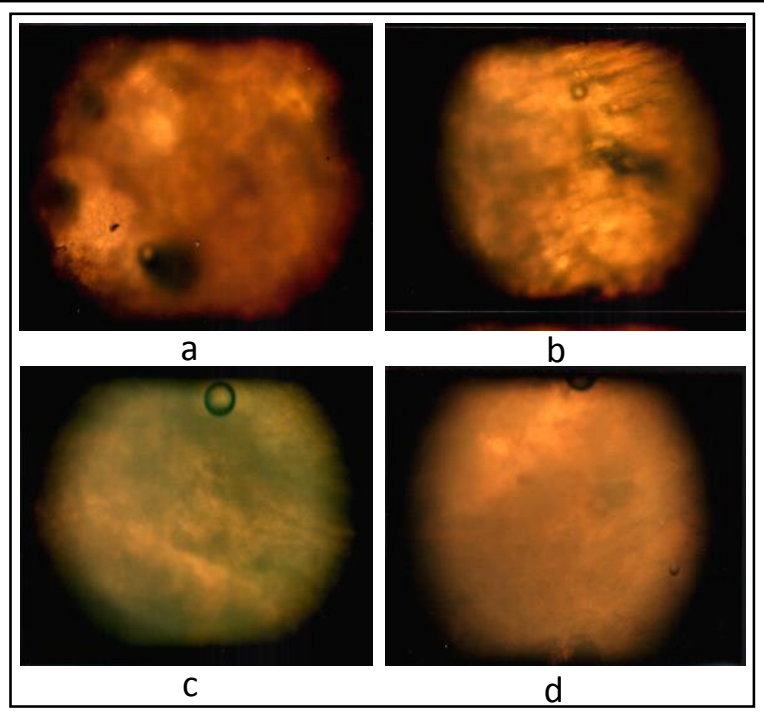

Gambar 8. Struktur penampang kamaboko ikan bandeng pada konsentrasi tepung terigu a). 5\%, b). $10 \%, \mathrm{c}) .15 \%$, d). $20 \%$
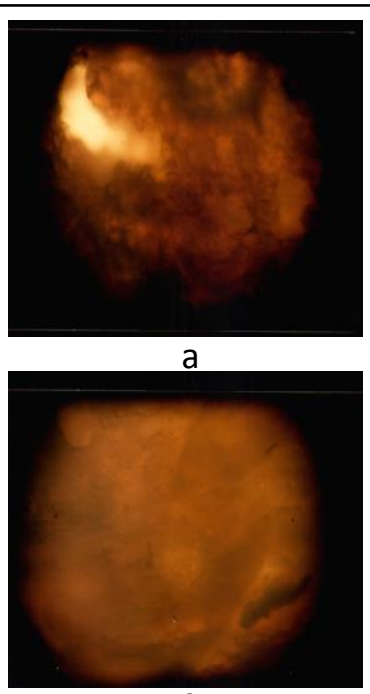

C

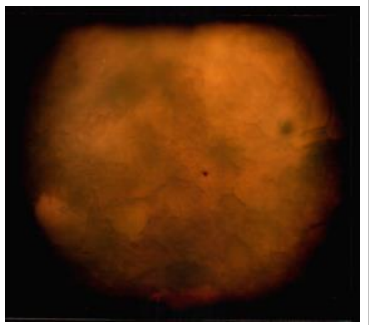

b

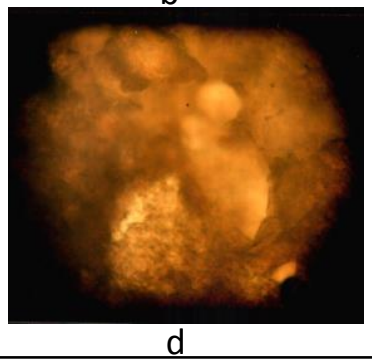

d
Gambar 9. Struktur penampang kamaboko ikan kembung pada konsentrasi tepung terigu a). $5 \%, \mathrm{~b}$ ). $10 \%, \mathrm{c}) .15 \%, \mathrm{~d}) .20 \%$

\section{Uji Organoleptik}

Penilaian dengan indera yang juga disebut penilaian organoleptik atau penilaian sensorik merupakan suatu cara penilaian yang sederhana. Penilaian dengan indera banyak digunakan untuk menilai mutu komoditi hasil pertanian dan makanan. Penilaian cara ini banyak disenangi karena dapat dilaksanakan dengan cepat dan langsung. Uji organoleptik dilakukan untuk mengetahui tingkat penerimaan panelis terhadap produk yang dihasilkan [15]. Uji yang dilakukan meliputi warna, aroma, penampakan, tekstur serta rasa [3].

\section{Warna}

Hasil uji organoleptik menunjukkan bahwa nilai rata-rata tingkat kesukaan panelis terhadap warna kamaboko berkisar 2,60-3,90 (tidak suka sampai agak suka). Nilai kesukaan tertinggi terhadap warna terdapat pada kamaboko jenis ikan bandeng $\left(\mathrm{A}_{1}\right)$ pada konsentrasi tepung terigu $5 \% \quad\left(\mathrm{~B}_{1}\right) \quad\left(\mathrm{A}_{1} \mathrm{~B}_{1}\right)$ sebesar 3,90 (agak suka mendekati suka) dan nilai kesukaan terendah terdapat pada kamaboko jenis ikan kembung $\left(\mathrm{A}_{2}\right)$ pada konsentrasi tepung terigu $20 \%\left(\mathrm{~B}_{4}\right)\left(\mathrm{A}_{2} \mathrm{~B}_{4}\right)$ sebesar 2,60 (tidak suka mendekati agak suka). Grafik nilai rata-rata uji organoleptik terhadap warna kamaboko dapat dilihat pada Gambar 10.

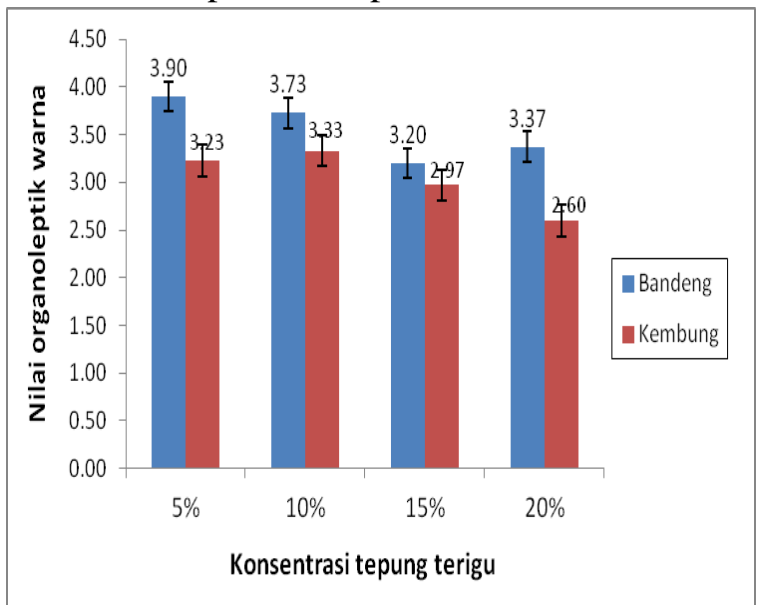

Gambar 10. Grafik Nilai Organoleptik Warna

Hasil uji kruskal wallis menunjukkan bahwa faktor jenis ikan (A) dan konsentrasi tepung terigu (B) memberikan pengaruh yang nyata terhadap warna kamaboko. Hal ini disebabkan jenis ikan (A) yang digunakan berbeda walaupun dengan penambahan tepung terigu (B) pada konsentrasi yang sama (5\%, $10 \%, 15 \%, 20 \%)$. Konsentrasi tepung terigu yang diberikan tidak cukup untuk memberikan perbedaan terhadap warna kamaboko menurut penilaian panelis.

Hasil uji lanjut Multiple Comparison menunjukkan terdapat perbedaan antar perlakuan. Gambar 10 dapat dilihat bahwa panelis lebih cenderung menyukai warna kamaboko jenis ikan bandeng $\left(\mathrm{A}_{1}\right)$ pada konsentrasi tepung terigu $5 \%\left(\mathrm{~B}_{1}\right)$ dengan nilai tertinggi 3,90 (agak suka mendekati suka) dibandingkan warna kamaboko ikan kembung $\left(A_{2}\right)$, dimana pada kamaboko ikan bandeng $\left(A_{1}\right)$ memperlihatkan warna yang lebih putih, 
sedangkan kamaboko ikan kembung $\left(\mathrm{A}_{2}\right)$ warnanya sedikit gelap. Bandeng (Chanos chanos) adalah salah satu spesies ikan berdaging putih. Ikan tersebut memiliki kandungan warna putih yang baik dan elastisitas gel sehingga dapat berkontribusi dalam membuat surimi yang berkualitas [16].

Grafik 10 juga menunjukkan terdapat adanya perbedaan warna antara ikan bandeng dan ikan gembung. Perbedaan itu disebabkan adanya protein aktomiosin terutama terdapat pada daging merah. Ilustrasi tersebut menunjukkan perbedaan warna kamaboko yang dihasilkan dari jenis ikan bandeng $\left(\mathrm{A}_{1}\right)$ dan ikan kembung $\left(\mathrm{A}_{2}\right)$ disebabkan kandungan daging merah (gelap) pada ikan kembung $\left(\mathrm{A}_{2}\right)$ lebih tinggi dibandingkan ikan bandeng $\left(\mathrm{A}_{1}\right)$.

Proses pencucian bertujuan untuk memperbaiki warna yang dihasilkan. Perlakuan pencucian daging ikan dengan air dingin dapat mengurangi kandungan pigmen, darah, dan lemak dalam daging ikan tetapi tidak secara sempurna menghilangkan bahan-bahan tersebut [15].

\section{Penampakan}

Penampakan adalah karakteristik pertama yang dinilai konsumen dalam mengkonsumsi suatu produk. Bila kesan penampakan produk baik atau disukai, maka konsumen baru akan melihat karakteristik yang lainnya seperti aroma, rasa, warna dan tekstur. Meskipun penampakan tidak menentukan tingkat kesukaan konsumen secara mutlak, tetapi penampakan mempengaruhi penerimaan konsumen. Produk pangan dengan bentuk rapi, bagus, utuh pasti lebih disukai oleh konsumen dibandingkan dengan produk yang kurang rapi dan tidak utuh [17].

Hasil uji organoleptik menunjukkan bahwa nilai rata-rata tingkat kesukaan panelis terhadap penampakan kamaboko berkisar 2,833,80 (tidak suka sampai suka). Nilai kesukaan tertinggi terhadap penampakan terdapat pada kamaboko jenis ikan bandeng $\left(\mathrm{A}_{1}\right)$ pada konsentrasi tepung terigu $5 \% \quad\left(\mathrm{~B}_{1}\right) \quad\left(\mathrm{A}_{1} \mathrm{~B}_{1}\right)$ sebesar 3,80 (agak suka mendekati suka) dan nilai kesukaan terendah terhadap penampakan terdapat pada kamaboko ikan kembung $\left(\mathrm{A}_{2}\right)$ pada konsentrasi tepung terigu $20 \%\left(\mathrm{~B}_{4}\right)\left(\mathrm{A}_{2} \mathrm{~B}_{4}\right)$ sebesar 2,83 (tidak suka mendekati agak suka). Grafik nilai rata-rata uji organoleptik terhadap penampakan kamaboko dapat dilihat pada Gambar 11.

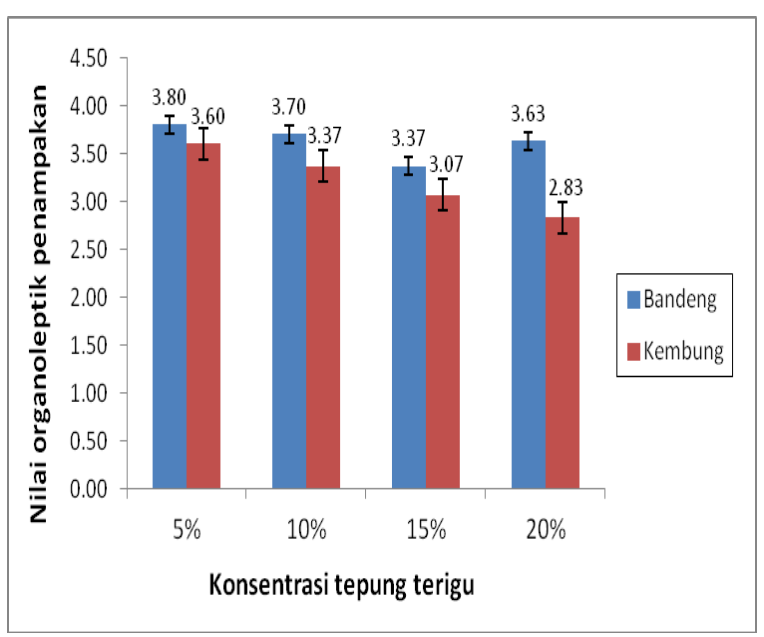

Gambar 11. Grafik Nilai Organoleptik Penampakan

Hasil uji kruskal wallis, menunjukkan bahwa faktor jenis ikan (A) dan konsentrasi tepung terigu (B) memberikan pengaruh nyata terhadap penampakan kamaboko. Hasil uji lanjut multiple comparison menunjukkan terdapat perbedaan antar perlakuan. Gambar 11 terlihat bahwa panelis cenderung menyukai penampakan kamaboko pada jenis ikan bandeng $\left(\mathrm{A}_{1}\right)$ dengan konsentrasi tepung terigu $5 \%\left(\mathrm{~B}_{1}\right)\left(\mathrm{A}_{1} \mathrm{~B}_{1}\right)$. Hal ini diduga karena produk kamaboko yang disukai tersebut memiliki penampakan yang baik, yaitu utuh dan rapi.

\section{Aroma}

Umnya kelezatan makanan ditentukan oleh aroma. Industri pangan menganggap sangat penting dilakukan uji aroma karena dapat dengan cepat memberikan hasil penilaian produksinya disukai atau tidak disukai.

Hasil uji organoleptik menunjukkan bahwa nilai rata-rata tingkat kesukaan panelis terhadap aroma kamaboko berkisar 2,83-3,23 (tidak suka sampai agak suka). Nilai kesukaan tertinggi terdapat pada kamaboko jenis ikan bandeng $\left(\mathrm{A}_{1}\right)$ pada konsentrasi tepung terigu $15 \% \quad\left(\mathrm{~B}_{3}\right) \quad\left(\mathrm{A}_{1} \mathrm{~B}_{3}\right)$ sebesar 3,23 (agak suka mendekati suka) sedangkan nilai kesukaan terendah terdapat pada kamaboko jenis ikan kembung $\left(\mathrm{A}_{2}\right)$ pada konsentrasi tepung terigu $5 \% \quad\left(\mathrm{~B}_{1}\right) \quad\left(\mathrm{A}_{2} \mathrm{~B}_{1}\right)$ sebesar 2,83 (tidak suka mendekati agak suka). Grafik nilai rata-rata uji organoleptik terhadap aroma kamaboko dapat dilihat pada Gambar 12. 


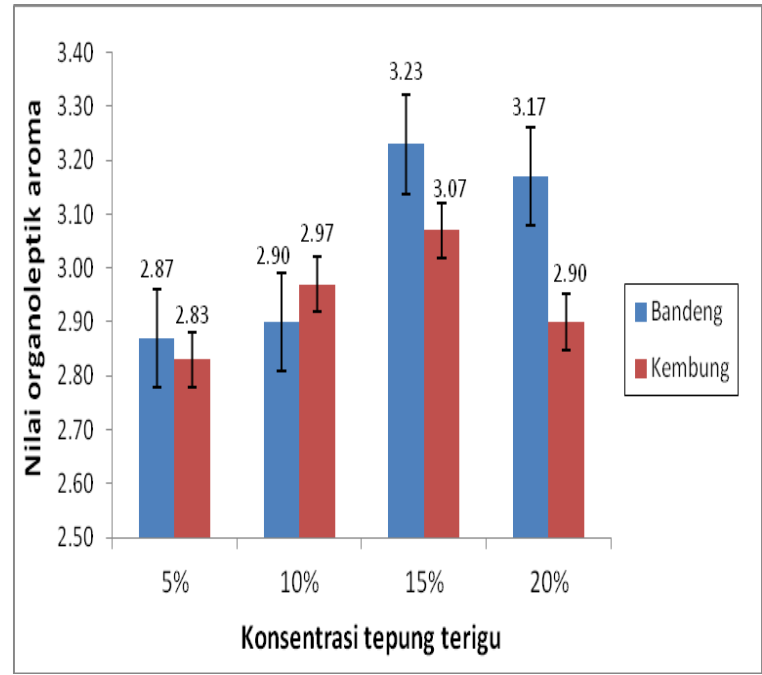

Gambar 12. Grafik Nilai Organoleptik Aroma

Hasil uji kruskall wallis menunjukkan bahwa faktor jenis ikan (A) dan konsentrasi tepung terigu (B) memberikan berpengaruh yang tidak nyata terhadap aroma kamaboko artinya semua kamaboko yang dihasilkan dengan perlakuan jenis ikan (A) yang berbeda dengan penambahan tepung terigu (B) pada konsentrasi yang sama memiliki tingkat kesukaan aroma yang cenderung sama terhadap kamaboko yang dihasilkan. Tepung terigu mempunyai aroma yang netral, sehingga penambahan tepung terigu tidak memberikan pengaruh yang berbeda terhadap aroma kamaboko.

Hal tersebut disebabkan bau anyir ikan pada kamaboko sudah berkurang. Berkurangnya bau pada kamaboko tersebut faktor bau anyir ikan yang telah hilang karena mengalami proses pengolahan, yaitu pada saat pencucian daging ikan dengan air dingin. Selama pencucian daging ikan dibersihkan dari darah, pigmen, lendir dan lemak disamping protein yang larut air [15].

\section{Rasa}

Hasil uji organoleptik menunjukkan bahwa nilai rata-rata tingkat kesukaan panelis terhadap rasa kamaboko berkisar 2,90-3,50 (tidak suka sampai agak suka). Nilai kesukaan tertinggi terhadap rasa terdapat pada kamaboko jenis ikan bandeng $\left(\mathrm{A}_{1}\right)$ pada konsentrasi tepung terigu $10 \%\left(\mathrm{~B}_{2}\right)\left(\mathrm{A}_{1} \mathrm{~B}_{2}\right)$ sebesar 3,50 (agak suka mendekati suka) sedangkan nilai kesukaan terendah terdapat pada kamaboko jenis ikan kembung $\left(\mathrm{A}_{2}\right)$ pada konsentrasi tepung terigu 20
$\% \quad\left(\mathrm{~B}_{4}\right) \quad\left(\mathrm{A}_{2} \mathrm{~B}_{4}\right)$ sebesar 2,90 (tidak suka mendekati agak suka). Grafik nilai rata-rata uji organoleptik terhadap rasa kamaboko dapa dilihat pada Gambar 13.

Hasil uji kruskall wallis menunjukkan bahwa faktor jenis ikan (A) dan konsentrasi tepung terigu (B) memberikan pengaruh yang nyata terhadap rasa kamaboko. Hal ini diduga karena jenis ikan yang digunakan sebagai bahan dasar pembuatan kamaboko berbeda sehingga rasa kamaboko yang dihasilkan juga berbeda walaupun dengan penambahan tepung terigu pada konsentrasi yang sama.

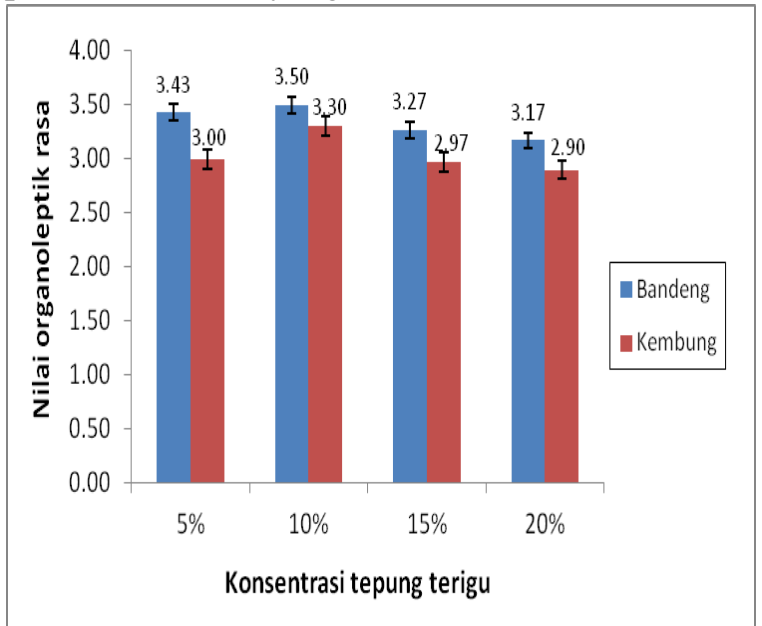

Gambar 13. Grafik Organoleptik Rasa

Hasil uji lanjut multiple comparison menunjukkan terdapat perbedaan antar perlakuan. Gambar 3 menunjukkan bahwa panelis cenderung lebih menyukai rasa kamaboko dengan bahan baku ikan bandeng dibandingkan ikan kembung pada penambahan tepung terigu $10 \%$.

\section{Tekstur}

Tekstur merupakan karakteristik yang sangat penting bagi produk gel yang bersifat elastis atau kenyal. Tekstur biasanya berhubungan dengan keempukan dan kekerasan produk. Pembentukan tekstur kamaboko terjadi ketika molekul-molekul protein dan granula pati mengembang pada waktu pemasakan. Penambahan bahan pengikat ditujukan untuk membentuk tekstur yang empuk (elastis) [18].

Hasil uji organoleptik menunjukkan bahwa nilai rata-rata tingkat kesukaan panelis berkisar 3,03-3,67 (agak suka). Nilai kesukaan tertinggi terhadap tekstur terdapat pada 
kamaboko jenis ikan bandeng pada konsentrasi tepung terigu 5\% yaitu 3,67 (agak suka mendekati suka). Sedangkan nilai kesukaan terendah terdapat pada kamabako jenis ikan kembung pada konsentrasi tepung terigu $20 \%$ yaitu 3,03 (agak suka). Grafik nilai rata-rata uji orgaleptik terhadap tekstur kamaboko dapat dilihat pada Gambar 14.

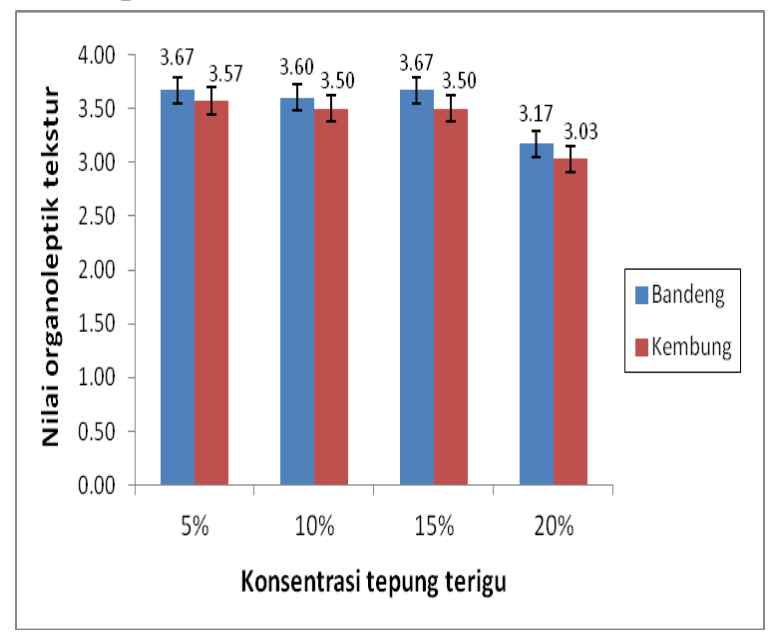

Gambar 14. Grafik Organoleptik Tekstur

Hasil uji kruskal wallis menunjukkan bahwa faktor jenis ikan (A) dan konsentrasi tepung terigu (B) memberikan pengaruh yang tidak nyata terhadap kamaboko yang dihasilkan. Semua kamaboko yang dihasilkan memiliki tekstur yang cenderung sama. Hal ini karena penambahan tepung terigu pada konsentrasi yang sama yaitu 5-20\% tidak cukup untuk membedakan tesktur yang dihasilkan.

\section{Uji Potong}

Uji potong dilakukan untuk memberikan taksiran secara subjektif yang dilakukan oleh 30 orang panelis. Pengujian dilakukan dengan cara memotong atau menggigit sampel antara gigi seri atas dan bawah, kemudian panelis memberikan penilaian terhadap tingkat kekenyalan produk tersebut sesuai dengan format yang telah ditentukan.

Hasil uji organoleptik menunjukkan bahwa nilai rata-rata tingkat kesukaan panelis berkisar 6,20-7,37 (dapat diterima sampai cukup kuat). Nilai uji potong tertinggi terdapat pada kamaboko jenis ikan bandeng $\left(\mathrm{A}_{1}\right)$ konsentrasi tepung terigu $5 \%\left(\mathrm{~B}_{1}\right)\left(\mathrm{A}_{1} \mathrm{~B}_{1}\right)$ sebesar 7,37 (cukup kuat). Sedangkan nilai terendah terdapat pada kamaboko jenis ikan kembung $\left(\mathrm{A}_{2}\right)$ pada konsentrasi tepung terigu $15 \%\left(\mathrm{~B}_{3}\right)\left(\mathrm{A}_{2} \mathrm{~B}_{3}\right)$ sebesar 6,20 (dapat diterima). Grafik nilai ratarata uji potong terhadap kamaboko dapat dilihat pada Gambar 15.

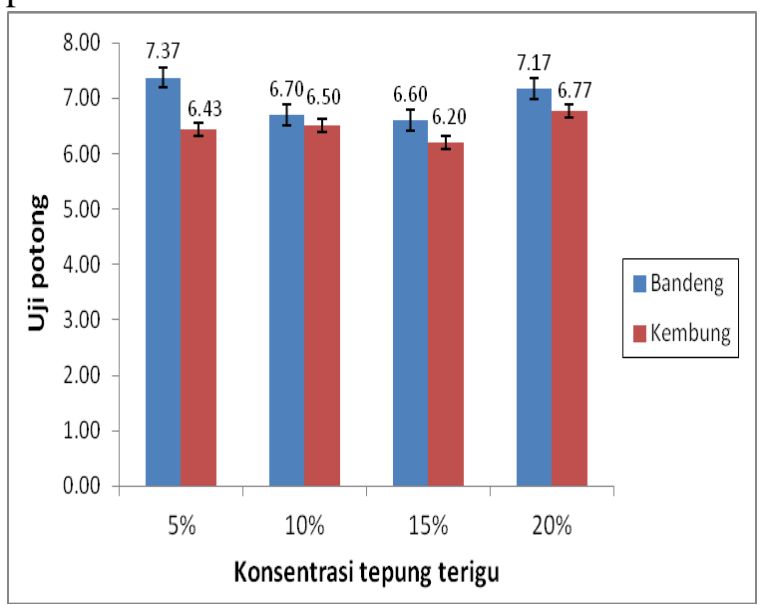

Gambar 15. Grafik Nilai Uji Potong

Hasil uji kruskal wallis menunjukkan bahwa faktor jenis ikan (A) dan konsentrasi tepung terigu (B) memberikan pengaruh yang tidak nyata terhadap uji potong kamaboko. Nilai rata-rata uji potong berada pada kisaran 6-7 yang berarti produk mempunyai tingkat kekenyalan yang dapat diterima sampai cukup kuat. Tidak adanya perbedaan yang nyata antar perlakuan, diduga panelis tidak bisa membedakan secara spesifik dan akurat antara kamaboko dengan nilai kekuatan yang hampir sama. Nilai uji potong ini mempunyai nilai yang serupa dengan parameter lain yang telah diukur sebelumnya yaitu kekenyalan kamaboko secara objektif.

\section{KESIMPULAN}

Faktor jenis ikan (A) dan konsentrasi tepung terigu (B) memberikan pengaruh yang nyata terhadap kekenyalan dan kekerasan kamaboko yang dihasilkan. Faktor jenis ikan (A) dan konsentrasi tepung terigu (B) memberikan pengaruh yang sangat nyata terhadap kadar air dan kadar protein kamabako yang dihasilkan. Hasil analisis kimia terhadap kadar protein kamaboko menunjukkan bahwa kamaboko jenis ikan bandeng pada konsentrasi tepung terigu 5\% adalah produk terbaik karena memiliki kadar protein tertinggi yaitu $11,67 \%$, sehingga dapat meningkat konsumsi protein masyarakat sebagai sumber gizi penting. Hasil uji organoleptik, 
tingkat penerimaan panelis terhadap warna, penampakan, aroma, rasa, tekstur serta uji potong menunjukkan bahwa kamaboko dengan perlakuan jenis ikan bandeng dengan penambahan tepung terigu pada konsentrasi $5 \%$ merupakan perlakuan terbaik.

\section{SARAN}

Perlu dilakukan penelitian lanjutan dengan memodifikasi proses pengolahan lainnya, seperti perbedaan suhu pemanasan dan waktu pemanasan sehingaa dapat memperbaiki mutu kamaboko yang dihasilkan

\section{DAFTAR PUSTAKA}

[1] R. Syarief, A. Irawati, "Pengetahuan Bahan Pangan untuk Industri Pertanian", PT. Mediyatama Sarana Perkasa, Jakarta, 1988.

[2] A. Fitri, $\mathrm{R}$ Baskara, Siswanti, "Penggunaan daging dan tulang ikan bandeng (chanos chanos) pada stik ikan sebagai makanan ringan berkalsium dan berprotein tinggi, Jurnal Teknologi Hasil Pertanian, vol. 9, no. 2, hal. 53-62, Agu 2017.

[3] T. Suzuki, "Fish And Krill Protein Processing Technology". Applied Science Publisher Ltd, London, 1981.

[4] F.G. Winarno, "Kimia Pangan dan Gizi", PT. Gramedia Pustaka Utama, Jakarta, 1997.

[5] FAO, "Food Composition Table For Use in East Asia". FAO Food Policy and Nutrition Division, Roma, 2005.

[6] M. Khaffidin,'Pengaruh Konsentrasi Tepung Tapioka terhadap Karakteristik Kamaboko Ikan Tambakan (Helostoma temminckii)", Skripsi, Institut Pertanian Bogor, 2003.

[7] S. Florensia, D. Pramesti, R.U. Nur, 2012. "Pengaruh ekstrak lengkuas pada perendaman ikan bandeng terhadap jumlah bakteri”, Unnes J Life Sci, vol 1, no. 2, hal. 113-118, Apr 2012.

[8] Depkes RI. 1992. Daftar Komposisi Bahan Pangan. Jakarta. Bharatara Karya Aksara

[9] M. Rumapar, "Fortifikasi tepung ikan (decapterus sp.) pada mie basah yang menggunakan tepung sagu sebagai subtitusi tepung terigu", Majalah BIAM, vol 9, no. 1, hal. 26 - 36, Jul 2015.

[10] O.R. Fennema, "Principle of Food Science", Marcel Dekker Inc, New York, 1976.

[11] Y. Fitrial, "Pengaruh Konsentrasi Tepung Tapioka, Suhu, dan Lama Perebusan terhadap Mutu Gel daging Ikan Cucut Lanyam (Carcharhinus limbatus)". Tesis, Institut Pertanian Bogor, 2000.

[12] S.T. Soekarto, "Dasar-Dasar Pengawasan dan Standarisasi Mutu Pangan". PAU Pangan dan Gizi, IPB, Bogor, 1990.

[13] P. Luna, H. Herawati,, S. Widowati, dan A.B. Prianto, "Pengaruh kandungan amilosa terhadap karakteristik fisik dan organoleptik nasi instan", Jurnal Penelitian Pascapanen Pertanian, vol. 12, no. 1, hal. 1-10, Jun 2015.

[14] G.O. Philips, P.A. Williams. Handbook of Food Proteins. Woodhead Publishing Limited. Cambridge, UK, 2011.

[15] D. Fardiaz,. "Kamaboko, produk olahan ikan yang berpotensi untuk dikembangkan", Media Teknologi Pangan, vol 1. IPB, Bogor, 1985.

[16] C. Anwar, C.Y. Tsao, H.I. Hsiao, "Effect of cryoprotectants on the quality of surimi during storage at $-20^{\circ} \mathrm{C} "$, Annals. Food Science and Technology, vol. 14, no. 2, hal. 199-205, Jun 2013.

[17] S.T. Soekarto, "Penilaian Organoleptik untuk Industri Pangan dan 
Hasil Pertanian”, Bhratara Karya Aksara, Jakarta, 1985.

[18] E. Tanikawa. "Marine Product In Japan". Koseisha Koseikaku Co. Ltd, Tokyo, Japan, 1985. 